\title{
Why WORSHIP? REVISITING A FUNDAMENTAL LITURGICAL QUESTION
}

\begin{abstract}
Author:
Johan Cilliers ${ }^{1}$
\end{abstract}

\section{Affiliation:}

${ }^{1}$ Faculty of Theology,

University of Stellenbosch,

South Africa

\section{Correspondence to:}

Johan Cilliers

e-mail:

jcilliers@sun.ac.za

\section{Postal address:}

Faculty of Theology,

University of Stellenbosch,

Private Bag x5018,

Stellenbosch, 7599

South Africa

\section{Keywords:}

worship; liturgy;

motivation; liturgical

practices; intention

\section{Dates:}

Received: 28 Aug. 2008

Accepted: 18 Nov. 2008

Published: 17 Apr. 2009

How to cite this article:

Cilliers , J., 2009, 'Why

worship? Revisiting a

fundamental liturgical

question', HTS Teologiese

Studies/Theological Studies

65(1), Art. \#126, 6 pages.

DOI: $10.4102 /$ hts.v65i1.126

This article is available

at:

http://www.hts.org.za
(C) 2009. The Authors. Licensee: OpenJournals Publishing. This work

is licensed under the

Creative Commons

Attribution License.

\section{ABSTRACT}

In this article the fundamental liturgical question as to the motive and intention of worship is addressed within the framework of four related liturgical tensions, namely between being and becoming, between time and space, between awe and expression, and between laughter and lament. In order to do this, some classical voices from the past are listened to, for instance, Schleiermacher, Kierkegaard, Moltmann, Tillich, Otto, Bakhtin and Buber, but more contemporary views are also considered. These four tensions are described in the light of the key terms: 'already' and 'not yet', and some implications for present-day liturgical practices are drawn.

\section{INTRODUCTION}

Why worship? This might seem like an obvious and fundamental question to ask, at least within the framework of liturgical theology, but the fact of the matter is that it is seldom posed (VanderWilt 2003:286). Other questions seem to occupy the minds of liturgical theologians, questions concerning the 'historical backgrounds and developments' of certain rites and ceremonies, or about the expertise entailed in 'how to perform' these rites and ceremonies, or 'what in effect happens' in worship. These questions are, of course, of paramount importance as they address the history (where from), the order (how to) and the phenomenology (what happens) of the worshipping event. But the more fundamental question 'Why worship?' often goes unasked and unanswered (cf. Newman 1988:1). Why do people gather in communities of faith to participate in the act that we call worship? What do they hope to accomplish? What are the motivations for worship and with what intention do people approach this event? Why worship? ${ }^{1}$

In this article these fundamental questions will be addressed within the sphere of four related liturgical tensions as an expression of the existential reality of our being human, namely between being and becoming, between time and space, between awe and expression, and between laughter and lament. If liturgy (leitourgia) is also meant to be liturgy of life (liturgy on the street), then existentialia, like these, should surely be brought into view and into liturgical consideration. In order to do this, some classical voices from the past are listened to, for instance, Schleiermacher, Kierkegaard, Moltmann, Tillich, Otto, Bakhtin and Buber, ${ }^{2}$ but more contemporary views are also considered.

These four tensions could also be translated and described in spiritual and theological terminology, i.e., in the light of the eschatological key terms: 'already', and 'not yet'. Many others could be added, of course, such as the tension between praising God and edifying believers; between honouring both the transcendence and the immanence of God; between engaging the mind, the emotions, and the will of human beings, etc. (cf. Tisdale 2001:175-188). It is important to note, however, that they are indeed 'tensions' which should not be resolved, as they give a profile to the existential dynamics that describe the concept: life. In my opinion it is exactly within the sphere of these tensions that we might find some answers to the above-mentioned fundamental questions.

\section{LITURGY BETWEEN BEING AND BECOMING}

Schleiermacher has become famous for, amongst other things, stating his belief that worship has its origins in inexpressible feeling ('unausprechliche Gefühl'; Schleiermacher 1988:166). With 'feeling' Schleiermacher does not mean conventional feelings, emotions or sentimentality, but rather the intuition or pre-reflective consciousness of a human being. It is the acute awareness of being an existing subject, of being part of reality. Simply put, it is the realisation, whether it be instantaneously or sporadically, that: 'I am here', or even more profoundly: 'I am'.

It is important to note that Schleiermacher's understanding of self-consciousness cannot be equated with existentialism, as, on the one hand, it is not identical with individualism, but rather is seen as arising from and being communicated within the religious community. It is not merely a solo discovery to say 'I am', but a shared experience of the faith community and the worshipper's innate feeling of finitude. On the other hand, and more importantly, Schleiermacher's views are not premised on an existentialist understanding of human freedom (which in itself is not wrong), but on the feeling of absolute dependence on God ('schlechthinniges Abhängigkeitsgefühl von Gott'; cf. Schleiermacher 1989:133 f). The discovery that 'I am' is complemented by the discovery that 'I am before God'. This innate feeling of finitude and dependence could be called a way of life, an attitude or a style, and should be constantly developed. Its primary aim is to foster a sense and taste for the infinite ('Sinn und Geschmack furs Unendliche'; cf. Mädler 2005:18).

1.This fundamental question could be understood on at least two levels, namely as pertaining to the reasons why people engage in worship, and why there is such a thing as worship. In my opinion these levels are intertwined, i.e., the motives and intentions of people coming to worship are intrinsically related to the theological question as to the existence of worship. Although this article tries to answer the question in a theological manner, certain existential realities, as described in four features, are continuously brought into dialogue the question in a with liturgical the field of human existentiality, but rather that they represent certain tensions that can be linked (theologically) to human experiences of liminality and as such, offer a valuable framework within which the above-mentioned dialogue can be fostered. Other existential features or tensions

2. These authors are cited because they speak explicitly about these tensions. Of course, many other classical authors have also addressed these issues, but lack of space precludes a detailed discussion of their contributions. 
Schleiermacher's views have, of course, been critiqued by many, and often severely (for a summary of some of the main arguments, cf. VanderWilt 2003:290f). It is, however, not the intention of the article to reopen this debate, but rather to acknowledge the fundamental dimension of self-consciousness (or subjectiveness as an existential category related to life) that Schleiermacher brings to the table. In worship, human beings discover that they are (here). Without this discovery, worship in the true sense of the word could hardly be possible. Worship should therefore create spaces where this deeply human need to discover who (and that) you are can be accommodated, and indeed fostered. In worship, the being-functions of human beings are to be considered before attending to the doing-functions; these beingfunctions can, however, not be manipulated or controlled (either by liturgical order or denominational confession), but are in effect part and parcel of the 'event of the liturgical encounter' between God and human beings.

The fostering of the being-functions of humans in liturgy could also be described in terms of what has been called a 'theology of affirmation'. Louw elucidates as follows:

A theology of affirmation ... seeks to deal with ontological issues that affect the status and identity of human beings. Within a Christian spiritual approach to life events, a theology of affirmation describes the status of our being human in terms of eschatology. Eschatology is understood as an ontological category that defines our being human in terms of the events of the cross and the resurrection ... Affirmation theology describes signification and ascribes human dignity and subject particularity. It emanates from the ontological "Yes" in Christ to our human being (as demonstrated through Baptism and celebrated in the Eucharist) and is demonstrated in new patterns of pneumaticliving (pneumatology and inhabitational theology).

(Louw 2008:30)

This brings us to the other element in this tension of liturgy. Human beings not only 'are' - they are also 'en route'. Their being is also a becoming. Their existence (existere) is always transformative and anticipatory, one could say transcendental (transcendere). According to Umberto Eco, being human means to be continuously busy with interpretation, with the generation of meanings, with the reading of signs, the discovery of relations, the telling of stories, the sharing of experiences, and the linking of cultural codes ( $c f$. Weyel 2005:326). We have not yet arrived. We are continuously immersed in the hermeneutics of life, and continuously participating in the future in an anticipatory manner.

The role of religion has often been described as a process through which experiences of contingency can be overcome ('Religion als Kontingenzbewältigungspraxis'; cf. Von Scheliha 2005:161; also Weeber 2005:234). This is of course true, but should not be understood in a negative way. Religion, as well as worship, is not meant to be purely a matter of crisis management. Life is contingent and this should also be reflected in worship services. But worship is also a way of being assured that the contingency of life does not have the final say. When I say: 'I am before God', I express the conviction that I am in the process of becoming what I should be, what God intended me to be, together with the community of faith.

This process of 'becoming what I should be' should, however, also not be misunderstood. In the New Testament sense of the word, this becoming is linked to the resurrection of Jesus Christ, and could therefore be described as an eschatological novum (Moltmann 1969:76). This novum does not only entail 'renewal', but rather the breaking through of the unexpected, the beginning of something 'radically' new. Therefore Christian hope (becoming what I should be) is not meant to be a one-way movement, a flight out of the present towards the future. It could rather be called two-way traffic, as the reality of the hope, the reality of being secured in the resurrection of Christ, constantly breaks through into the present. The future itself becomes present (Moltmann 1969:78). In Christian understanding future is not so much futurum, as it is adventus - future continuously 'presenting' itself. Christian hope therefore is not only becoming what I should be, but at the same time also being what I am already!

This understanding of hope is of crucial understanding not only for anthropology, but also for the way in which it impacts on our understanding of liturgy. This will be discussed in more detail in the section entitled Liturgy between laughter and lament.

\section{LITURGY BETWEEN TIME AND SPACE}

The tension between being and becoming could also be described in terms of another tension, namely between time and space. Time and space could be referred to as the basic structures within which we exist, the 'Hauptstrukturen der Existenz' (Tillich 1962:187). Everything that exists, also movement, takes place within time and space. Time and space are related to one another, but are also in constant tension with one another. When this tension is broken, dangerous and inhumane myths may be formed. Tillich (1962:187) refers to the classic symbols of a 'circle' (representing enclosed space) and a 'line' (representing linear time). If, for instance, space is understood as an exclusive entity (circle), it attains eternal characteristics. Therefore this exclusive circle must constantly be shattered by the line of time, reminding space of its inherent transience.

According to Tillich (1962:190-191), certain forms of nationalism have always operated from an exclusivist understanding of space, and many of these nationalistic myths have also corrupted the true understanding and function of time: instead of time interrupting exclusivity, it is now transformed into a (eternal!) cycle of time. The latter somehow also signifies the victory of space over time, because time then becomes another eternal, repetitive reality. For instance, in the eternal, cyclical events of birth and death, nothing new and surprising can happen. Where this happens - that is, where the gods of space conquer and corrupt time - life becomes truly heathenised.

The role of the prophets has always been to conquer space that has become institutionalised as eternal. They point towards something new. They indicate a direction, presupposing a beginning and an end, which contradicts the tendency to strap God down in space, as if God was just another clan god. In this way the tragic and repetitive circle of eternalised space is broken, interrupted, and the God of history acknowledged and worshipped. Indeed: 'Der Gott der Zeit ist der Gott der Geschichte. Das heist vor allem, dass er der in der Geschichte auf ein End-Ziel hinwirkende Gott ist' (Tillich 1962:194).

Heimbrock has carried out some interesting research on our understanding of time. According to him, children up to the age of six have an understanding of 'spatial time' only, that is, they can measure time in terms of spatial changes or transferences (for instance, being in the bedroom or outside in the garden). Between the ages of six and seven spatial time becomes 'compartmental time', which means that children now measure time in terms of 'before' and 'after', or 'short time' and 'long time', although these pockets of time are still not linked in a logical coherence. Only after the age of seven does time become 'linear time', that is, time that moves forward or passes by in a successive manner (Heimbrock 1993:63-64).

A mature theology operates with a linear understanding of time, understood in the eschatological perspective as described in the section Liturgy between being and becoming. In the process it affirms human beings as not being subjected to a fatalistic and tragic repetition of time, or in the words of Tillich:

Im Menschen aber ist der Sieg der Zeit innerhalb des Endlichen möglich, denn er besitzt die Fähigkeit, auf etwas über seinen Tod Hinausgehendes hin zu wirken. Er ist dazu befähigt, Geschichte zu haben und kann sogar den tragischen Tod in Familien und Völkern 
transzendieren, wodurch er den Kreis der Wiederholung auf etwas Neues hin durchbricht. Und da er dazu befähigt ist, repräsentiert er den Sieg der Zeit, jedenfalls den potentiellen, wenn auch nicht immer den tatsächlichen Sieg.

(Tillich 1962:188)

Both the Old as well as the New Testament express God's history-making action predominantly with the help of 'linear' time categories. ${ }^{3}$ The linear passing of time (history) thus is not conceived as an abstract continuity of time, but rather the Godgiven content of certain moments in history. God's objectives for the world move to a consummation; things do not just go ahead or return to the point where they began. Although the fall of humanity made history meaningless and monotonous, it is indeed God's intervention that (always) imparts purpose and new meaning. Linear time is not a sequence of inevitable events, but moments, 'days', in which God brings his objective for the world closer to its conclusion. These are unrepeatable moments, kairos moments, in which God allows a specific objective to be fulfilled at a specific time. The fullness of time, with Christ's coming, the ephapax of his crucifixion, is the most striking example of this (Kümmel 1974:141-146; also Cilliers 2006:21).

Destructive myths always tend to 'change history into nature' (Barthes 1964:113). Time is arrested and fixed in space. In liturgy, however, we worship the God of history, the God of Abraham, Isaac and Jacob, that is, the God of the past, but therefore also the God of the present and future. We celebrate the fact that, although we are bound to space and time, we have also been liberated from the gods of space, and the abstractions of cyclical time. We celebrate the fact that we are here, being human beings in space and time, but also that we are in the process of 'becoming', being taken forward towards the telos of history. We protest (prophetically) against the formation of destructive myths that endeavour to reduce God to spatial interests, whether they are nationalistic, socio-political, or cultural. We lament any fatalistic understanding of time or history, which enslaves us within a cyclical fait accompli. We refuse to minimise the devastating effect that destructive myths have had and still have on our world, but we do not lament without hope, as we move forward with the God of history (Duff 2005:11; cf. also Cilliers 2007b:155-176). This tension between celebration and lament is discussed in more detail in the section entitled Liturgy between laughter and lament.

\section{LITURGY BETWEEN AWE AND EXPRESSION}

The tensions between being and becoming, and between time and space, could be described from yet another angle, namely in terms of the tension between awe and expression. We have already noted that Schleiermacher (1988:166) understood the origin of religion to be rooted in the inexpressible feeling of being and the absolute dependency on God. For him, worship begins when a human being knows 'I am'. But saying ' $\mathrm{I}$ am' is not meant to be an individualistic experience - it always take place in communion with others. But more than that, it is also an expression that is complemented by saying 'I am before God'.

Rudolf Otto found many corresponding themes between his own thought and that of Schleiermacher, especially the idea that human beings have an innate feeling of dependency, but he used the concept of 'creatureliness' ('Kreaturgefühl') to express this (Otto 1917:8f; $c f$. also Schneider 2005b:103). For Otto, religion was the experience of the mystery of God, which shone through the veil of time and all our experiences of transience.

Otto distinguished between three religious feelings, namely inspiration, consecration and trust ('Begeisterung, Ergebung und Andacht'; Otto 1917:12f). The key concept that held all of this 3.In some instances, for example, in the Wisdom tradition, we do find the concept of cyclical time in my view, the biblical understanding of cyclical time does not oppose the notion of linear time. Within licear time there are certain occurences that repeat (e.g., seasons), but these repetitions are never understood as the inevitable, unpredictable fruits of fate. Cyclical events can be seen as part of the linear movement towards the Day of the Lord, even if this Day sees many fulfilments. together was his understanding of the numinous - according to him this was the experience that formed the a priori, the nucleus and essence of all religion. The numinous is 'das Heilige minus seines sittlichen Momentes und... minus seines rationales Momentes überhaupt' (1917:6).

According to Otto, this numinous mystery of the Holy God can be experienced in two ways: as attraction (fascinosum) or as object of fear (tremendum). In our approach to God we normally undergo both these experiences - hence God could rightly be called a mysterium tremendum et fascinans. We simply stand in awe before God. We are attracted, but at the same time also want to flee from this mystery. We have no words left to describe what we experience. It is truly an inexpressible feeling, best 'articulated' in the awe of silence ( $c f$. Schneider 2005b:104). As a matter of fact, the ultimate goal of the whole of creation, including people, is to worship in this way, to breathe out (stop speaking), in order to come into the rest of God, and to find security in his breath (Cornehl 2005:39). To be silent in God's presence, however, does not mean to be inactive; on the contrary, it could be described as a focused awe and an attentive silence (Richter 2005:341).

It must be stressed, however, that this feeling of awe is experienced precisely within the tension of a relation. The feeling itself is not the real element in the relationship with God. Feelings are a 'mere accompaniment' to the relationship, they have their place in its polarity ( $c f$. Buber 1958:81). On the other hand, the subject with his or her inexpressible feelings is not absorbed (or extinguished) in a mystical manner into God. It remains a true relationship, an 'I and You', in which the inexpressible feeling of 'I am' is always fulfilled by 'You are'. Buber provides the classic articulation:

Men do not find God if they stay in the world. They do not find Him if they leave the world. He who goes out with his whole being to meet his Thou and carries to it all being that is in the world, finds Him who cannot be sought. Of course God is the "wholly Other"; but He is also the wholly same, the wholly Present. Of course He is the Mysterium Tremendum that appears and overthrows; but $\mathrm{He}$ is also the mystery of the self-evident, nearer to me than my I.

(Buber 1958:79)

In awe before the mysterium tremendum et fascinans we become silent. Words and concepts become redundant. Silence itself becomes an expression of being and meaning. We are reminded of the fact that we are not (yet) able to articulate what we see and experience, because what we see now is like a dim image in a mirror (1 Cor 13:12). And yet we see and experience so much that we are (already) enabled to stutter a few words about this.

Otto understood this tension between the 'already' and the 'not yet'. Whilst accepting the importance of rationality, he also stressed the fact that the mystery of God cannot be expressed in concepts only. But it must to be expressed. For that it needs the enrichment of symbolism and analogies (Otto 1917:6f). This is the tension that is basic to all worship services: the awe in God's presence is inexpressible, but somehow it must and should be expressed. 'As a matter of fact, liturgy could be called the oscillation between awe and expression'.

According to Cornehl (2005:275-287), the basic structure of the early Christian's worship gatherings was geared to creating spaces for orientation, affirmation, integration and, importantly, also expression. Worship takes place in awe, but it also needs language, symbolism and embodiment to express this awe. The form of expression that is most suited for this would probably be metaphorical language. According to Janet Soskice:

Our concern is with conceptual possibility rather than proof, and with a demonstration that we may justly claim to speak of God without claiming to define Him, and to do so by means of metaphor. Realism accommodates figurative speech which is reality depicting without claiming to be directly descriptive.

(Soskice 1985:148) 
The original Greek understanding of the word metaphora denotes its function as a language structure that conveys meaning (metaphora $=$ meta + phora, 'across' + 'carry'). McFague (1978:4) describes this basic function of metaphor as follows: 'a word used in an unfamiliar context to give us new insight; a good metaphor moves us to see our ordinary world in an extraordinary way'.

In theological-liturgical terms this means looking at life through a different lens, namely the lens of the Gospel ('If anyone is in Christ, he or she has become a new creation; the old is gone, the new has come'; 2 Cor 5:17). In a sense it means looking at known realities as if for the first time, to see their uniqueness as if they have now once again become an unknown reality - very much like the 'Verfremdungseffek' that Bertolt Brecht propagated (cf. Roth 2006:48; also Friedrich 2001:54). This art of observation does not primarily concern the question: 'What do I see?' but rather: 'Why do I see?' and 'How do I see?' (Schneider 2005a:310311). Liturgy implies optical reorientation; calls for liturgists who see our ordinary world in an extraordinary way, and who are able to express this insight in metaphorical language and symbolic acts.

Without metaphorical language we cannot talk about the mysterium tremendum et fascinans. Metaphorical language helps us in this regard exactly because it is so open ended - metaphors have no set 'meaning' and their effect cannot be predicted (Ricoeur 1975:152f). Metaphors need and create imagination in order to function. They open up imaginative vistas of an alternative reality (. Cilliers 2007a:126-127). Their uniqueness lies inter alia therein that they operate with paradoxes, for instance, with the presupposition that something can 'be' and simultaneously 'not be'; that something can be 'already', but at the same time 'not yet'. In this sense, they are suitable for eschatological expression, or as Ringleben contends:

'Die Metapher ist theologisch eine sprachliche Abbreviatur von Gottes eschatologischem Wirken, oder auch: die sprachliche Struktur einer Metapher reflektiert den Rythmus göttlichen Handelns überhaupt'.

(Ringleben 2003:229-230)

If liturgy is indeed the oscillation or tension between awe and expression, the pacifying or eradication of this tension could have dire consequences for worship. If, for instance, the awe in the presence of the mysterium tremendum et fascinans is lost or domesticated, worship services could become nothing more than structured religious gatherings, which in themselves may seem coherent and functional, but are no longer truly worship. Empirical research has shown that congregants in fact place a high premium on 'the experience of the mystery of God' when attending worship services; as a matter of fact, it is listed as the highest priority (Long 2001:14f).

If, on the other hand, liturgy is not capable of expressing this mystery, that is, if worshippers are not given liturgical language to express their awe and symbolical acts to embody it, the worship service becomes an abstraction from life. Then the God images that are evoked become meaningless, in the sense that they cannot be related to day-to-day existence. Awe and mystery must be translated metaphorically in such a manner that liturgy becomes the liturgy of (everyday) life.

\section{LITURGY BETWEEN LAUGHTER AND LAMENT}

The eschatological tension between 'already' and 'not yet' can also be described as a tension between celebration (or laughter) and lament. This tension is only understood within the 'theological framework of hope'. Christian hope does not necessarily alleviate the realities of present conflict and suffering, nor does it necessarily make them more palatable; on the contrary, it could intensify these experiences (Moltmann 1971a:146). When the community of faith knows that the future is present, it receives new language (modes of expression) and new inspiration to protest against the conflict and suffering of the present. Liturgy always carries within it this inescapable paradox: it 'celebrates' the reality of being, also of a new being, but at the same time, and exactly because of the reality of this new being, it 'laments' the fact that there are still other realties that hamper us in becoming what we are. We could indeed say:

Christian worship is inherently eschatological - calling us to hope in God's present and coming reign, even as we name the realities that distort and oppose that reign in our world.

(Tisdale 2001:182).

The two-pronged liturgical question in this regard would be: do our worship services create spaces where we indeed celebrate the presence of God's future (also 'being' part of it); but do they also create spaces where we can lament over experiences of contingency, refusing to gloss over the conflict and suffering in this world (thus acknowledging that we are still in a process of 'becoming')? Or has our 'praise and worship' become shallow and our lament cheap? The latter seems to be the inevitable result when the eschatological tension (between being and becoming, time and space, and awe and expression) is sidestepped or softened.

This tension between celebration and lament seems to have been lost to a large extent in many worship services. When this happens, celebration ironically enough becomes just another consumeris activity in a market-driven society in which weakness and failure, and therefore lament, can have no place. Then liturgists (and praise and worship teams) try to compete not only with their counterparts, but with contemporary musical and other artistic performers. In this 'performance' success remains the key word. Arbuckle finds this mentality a sad state of affairs and contends that:

This is a thoroughly pathetic and frightening picture of a deathdenying culture, for just as we seek to deny physical death, so also we are apt to ignore all kinds of painful personal and social loss. We have developed a pervasive mythology in which success is the hallmark of Western identity and failure or loss has no place in it.

(Arbuckle 1991:44)

If this happens, lament - if it is still present - becomes institutionalised, mechanical and meaningless. One could say: lament loses its eschatological tension and urgency. It has become complacent and domesticated, satisfied with being without becoming, with clichés not born out of awe, and being fixed in space indeterminately.

Within the eschatological tension of 'already' and 'not yet' lament retains its depth and dynamics; but it is also accompanied by celebration that anticipates and enjoys the present future. In true liturgy the eschatological laugh of the redeemed must always be heard. Therefore, besides lamenting, we need also to embrace a theology of laughter. Even from Renaissance times laughter was understood to offer new and surprising insights into reality. According to Bakhtin:

The Renaissance conception of laughter can be roughly described as follows: Laughter has a deep philosophical meaning, it is one of the essential forms of the truth concerning the world as a whole, concerning history and man; it is a peculiar point of view relative to the world; the world is seen anew, no less (and perhaps more) profoundly than when seen from the serious standpoint. Therefore, laughter is just as admissible in great literature, posing universal problems, as seriousness. Certain essential aspects of the world are accessible only to laughter.

(Bakhtin 1984:66)

In a world full of pain we need the liberation of laughter. As a matter of fact, what we sorely need is not only lamenting, but also laughter. Lament and laughter are closer to one another than one tends to think: they are two sides of the same coin. Laughter and lament complement one another. Perhaps one could venture to say that the meaning of life is found exactly in the interaction between laughter and lament ( $c f$. Kierkegaard 1959:631). Death is swallowed up in the comical cry: 'Where is your victory? 
Where is your sting?' ( $c f .1$ Cor 15:55). Meaning (life triumphing over death) is born out of an empty tomb. It is a laughing matter. In Eugene O'Neill's play, Lazarus Laughs, Lazarus emerges from the tomb with a bellow of laughter (as quoted in Wirt 1991:44). Meaninglessness is overcome by mirth.

At the cross it seems as though all joy has vanished, but according to Moltmann:

Easter is an altogether different matter. Here indeed begins the laughter of the redeemed, the dancing of the liberated and the creative game of new, concrete concomitants of the liberty which has been opened for us, even if we still live under conditions with little cause for rejoicing.

(Moltmann 1971b:50)

Long calls for a renewed joy in preaching (and liturgy) exactly because of this theology of Easter mirth, and states:

Because God in Christ has broken the power of sin and death, Christian congregations and their preachers are free to laugh at themselves, and they can also laugh at the empty gods of pride and greed. They can mock hell and dance on the grave of death and sin. We do have much to cry about. But let the dancing begin.

(Long 1989:16)

\section{CONCLUSION}

Worship is an in-between experience. It takes place within the dynamic spheres of several tensions, with the tension between the 'already' and the 'not yet', forming the leitmotiv. It could rightly be called an 'experience of liminality', which implies an ambiguous phase between two situations or statuses. Often this in-between space or liminal experience is filled with potential and creativity, but also with risk and danger. It breathes, according to Franks and Meteyard:

A sense of displacement, that sense of being in no man's land, where the landscape appears completely different: there is no discernable road map, and where the journeyer is jolted out of normalcy.

(Franks \& Meteyard 2007:216).

Characteristically, the liminal phase is constituted by the convergence or interweaving of qualities of both categories between which it is sandwiched: 'Since the liminal is neither fully one type of space (category) nor the other, it will take on aspects of both; it is this indeterminacy of quality and therefore predictability that creates the aspect of danger' (Kunin 1989:30).

Indeed, worship is a dangerous enterprise. Liturgy can be lethal - for normative discourse and conventional theory. But it is exactly in the high-voltage tension between being and becoming, between time and space, between awe and expression, and between laughter and lament, that the sparks of true worship fly.

\section{REFERENCES}

Arbuckle, G.A., 1991, Grieving for change: A spirituality for refounding communities, Cassell, Strand.

Bakhtin, M., 1984, Rabelais and his world, transl. H. Iswolsky, Indiana University Press, Bloomington.

Barthes, R., 1964, Mythen des Alltags, Peter Lang, Frankfurt.

Buber, M., 1958, I and Thou, 2nd edn., transl. R.G. Smith, T \& T Clark, Edinburgh.

Cilliers, J.H., 2006, God for us?: An analysis and evaluation of Dutch Reformed preaching during the Apartheid years, Stellenbosch University Press, Stellenbosch.

Cilliers, J.H., 2007a, Binne die kring-dans van die kuns: Die betekenis van estetika vir die gereformeerde liturgie, Stellenbosch University Press, Stellenbosch.

Cilliers, J.H., 2007b, 'Preaching as language of hope in a context of HIV and AIDS', in C.J.A. Vos, L.L. Hogan \& J.H. Cilliers (eds.), Preaching as a language of hope: Studia Homiletica 6, pp. 155-176, Protea Book House, Pretoria.

Cornehl, P., 2005, 'Die Welt ist voll von Liturgie: Studien zu einer intergrativen Gottesdienstpraxis', in U. Wagner-Rau (Hrsg.), Praktische Theologie Heute, Kohlhammer, Stuttgart.
Cornehl, P., 2006, Der Evangelische Gottesdienst - Biblische Kontur und neuzeitliche Wirklichkeit, Band 1, Theologischer Rahmen und biblische Grundlagen, Kohlhammer, Stuttgart.

Duff, N.J., 2005, 'Recovering Lamentation as a practice in the Church', in S.A. Brown \& P.D. Miller (eds.), Lament: Reclaiming practices in pulpit, pew, and public square, pp. 3-14, Westminster John Knox, Louisville.

Franks, A. \& Meteyard J., 2007, 'Liminality: The transforming grace of in-between places', The Journal of Pastoral Care and Counseling 61(3), 215-222.

Friedrich, M.A., 2001, Liturgische Körper: Der Beitrag von Schauspieltheorien und - techniken für die Pastoralästhetik. Praktische Theologie Heute, Kohlhammer, Stuttgart.

Heimbrock, H.G., 1993, Gottesdienst: Spielraum des Lebens. Sozial - und Kulturwissenschaftliche Analysen zum Ritual in praktischtheologischem Interesse, Kok, Kampen. (Deutscher Studien Verlag)

Kierkegaard, S., 1959., Philosophische Brosamen und Unwissenschaftliche Nachschrift, Unter Mitwurking von Niels Thulstrup und der Kopenhagener Kierkegaard-Gesellschaft herausgegeben von Hermann Diem und Walter Rest, Bei Jakob Hegner, Köln.

Kümmel, W.G., 1974, Theology of the New Testament, SCM, London.

Kunin, S.D., 1998, God's place in the world: Sacred space and sacred place in Judaism, Cassell, London.

Long, T.G., 1989, The witness of preaching, Westminster, Louisville.

Long, T.G., 2001, Beyond the worship wars: Building vital and faithful worship, Alban Institute, Herndon.

Louw, D.J., 2008, Cura Vitae: Illness and the healing of life in pastoral care and counselling, Lux Verbi, Wellington, BM.

Mädler, I., 2005, 'Friedrich Schleiermacher: Sinn und Geschmack fürs Unendliche', in V. Drehsen, W. Gräb \& B. Weyel (Hrsg.), Kompendium Religionstheorie, pp. 15-26, Vandenhoeck \& Ruprecht, Göttingen.

McFague, S., 1978, Speaking in parables, Fortress, Philadelphia.

Moltmann, J., 1969, Geloof in de toekomst, Ambo, Utrecht.

Moltmann, J., 1971a, De mens: Christelijke antropologie in de conflicten van deze tijd, Ambo, Bilthoven.

Moltmann, J., 1971b, Theology and joy, SCM, London.

Newman, R., 1988, Worship as praise and empowerment, Pilgrim, New York.

Otto, R., 1917, Das Heilige: Über das Irrationale in der Idee des Göttlichen und sein Verhältnis zum Rationalen, Biederstein, München.

Richter, O., 2005, Anamnesis - Mimesis - Epiklesis: Der Gottesdienst als Ort religiöser Bildung, Evangelische Verlagsanstalt, Leipzig.

Ricoeur, P., 1975, 'Parole et symbole', RevSR 49, 142-161.

Ringleben, J., 2003, Metapher und Eschatologie bei Luther. Zeitschrift für Theologie und Kirche (100 Jahrgang Heft 2) June 2003, 223-240.

Roth, U., 2006, 'Die Theatralität des Gottesdienstes', in W. Gräb \& M. Meyer-Blanck (Hrsg.), Praktische Theologie und Kultur 18, Gütersloher Verlagshaus, München.

Schleiermacher, F., 1988, On Religion: Speeches to its cultured despisers, transl. R. Crouter, Cambridge University Press, Cambridge.

Schleiermacher, F., 1989, The Christian faith, transl. H.R. Mackintosch \& J.S. Stewart, T \& T Clark, Edinburgh.

Schneider, J., 2005a, Religion in der Krise: Die bildenden Künstler Ludwig Meidner, Max Beckmann und Otto Dix meistern ihre Erfahrung des Ersten Weltkriegs, Band 16 PThK, W. Gräb \& M. Meyer-Blanck (Hrsg.), Gütersloher Verlagshaus, München.

Schneider, J., 2005b, 'Rudolf Otto: Religion als Begegnung mit dem Heiligen', in V. Drehsen, W. Gräb \& B. Weyel (Hrsg.), Kompendium Religionstheorie, pp. 97-107, Vandenhoeck \& Ruprecht, Göttingen.

Soskice, J.M., 1985, Metaphor and religious language, Clarendon, Oxford.

Tillich, P., 1962, Auf der Grenze: Aus dem Lebenswerk Paul Tillichs, Evangelisches Verlagswerk, Stuttgart. 
Tisdale, L.T., 2001, 'Navigating the contemporary worship narrows: Channel markers for deep waters', in B.K. Blount \& L.T. Tisdale (eds.), Making room at the table: An invitation to multicultural worship, pp. 175-188, Westminster John Knox, Louisville.

VanderWilt, J., 2003,' "Why worship?": Schleiermacher speaks to the question', Scottish Journal of Theology 56(3), 286-307.

Von Scheliha, A., 2005, 'Arnold Gehlen: Religion als Kontingenzbewältigungspraxis auf der Rückseite des Lebens', in V. Drehsen, W. Gräb \& B. Weyel (Hrsg.) Kompendium Religionstheorie, pp. 158-169, Vandenhoeck \& Ruprecht, Göttingen
Weeber, M., 2005, ‘Die Kontingenzbewältigungspraxis der sichtbaren Religion', in V. Drehsen, W. Gräb \& B. Weyel (Hrsg.), Kompendium Religionstheorie, pp. 226-238, Vandenhoeck \& Ruprecht, Göttingen.

Weyel, B., 2005, 'Umberto Eco: Religion als poetisches Konzept der Weltdeutung', in V. Drehsen, W. Gräb \& B. Weyel (Hrsg.), Kompendium Religionstheorie, pp. 317-328, Vandenhoeck \& Ruprecht, Göttingen

Wirt, S.E., 1991, 'The heresy of the serious', Christianity Today 35. 